\title{
Preliminary observations of Osmia coerulescens as a pollinator of herbage seed crops
}

\author{
R.G. PURVES ${ }^{1}$, P.T.P. CLIFFORD ${ }^{1}$ and B.J. DONOVAN ${ }^{2}$ \\ ${ }^{1}$ AgResearch, PO Box 60, Lincoln, New Zealand \\ ${ }^{2}$ Donovan Scientific Insect Research, Private Bag 4704, Christchurch, New Zealand
}

\begin{abstract}
The availability of large numbers of pollinators is critical to the efficient seed production of crosspollinated species of herbage legumes. The honey bee is the predominant pollinator of crops in New Zealand. There are risks in being solely dependent on the honey bee for pollination. Honey bee diseases and mites have reduced bee numbers in many parts of the world. The floral morphologies of some species such as tetraploid red clovers and lucerne are unsuited to pollination by honey bees. Other than in some localised areas, alternative pollinators have had little impact on improving pollination of these species in New Zealand. In 1995, Osmia coerulescens L. was introduced into New Zealand to be evaluated as an alternative, managed pollinator for herbage seed crops. Results from the $1997 / 98$ season show that $O$. coerulescens can be stored at $2-3^{\circ} \mathrm{C}$ with low mortality until the bees are 9 months old. When stored to 10.5 months of age, reproductive vigour was lost and mortality was high. The potential multiplication rate of this bee is high, especially in the first generation of a season. Managing the bees to emerge during summer rather than spring as occurs naturally had no effect on bee reproduction. The bee also successfully reproduced when retricted to white clover flowers as the only source of pollen and nectar. The wasp parasitoid Melittobia spp. destroyed large numbers of developing bees resulting from the nesting of 2nd-generation bees. Control of Melittobia spp. is discussed.
\end{abstract}

Keywords: management, Melittobia spp., Osmia coerulescens, pollination

\section{Introduction}

The availability of large numbers of pollinators is essential to maximise seed production of cross-pollinated species of herbage legumes. The European honey bee (Apis mellifera L.) is the predominant pollinator in New Zealand. To achieve good pollination in seed crops commercial beekeepers site bee colonies near the crops. The financial return for the beekeeper is in the value of the honey produced. Other bees such as feral honey bees and bumble bees contribute to pollination, but their numbers tend to be erratic and their impact on pollination is more variable than that of managed honey bee colonies.

There are risks associated the New Zealand's dependence on the honey bee for pollination of white clover (Trifolium repens L.), the seed of which is an important export earner. The mite Varroa jacobsoni Oud., originally an ectoparasite of Asian honeybee (Apis cerana $\mathrm{F}$.), is now one of the most destructive pests of the European honey bee. It has rapidly spread throughout Europe and North and South America and has been reported as close to New Zealand as Papua New Guinea (Matheson 1993). V. jacobsoni, together with endoparasitic tracheal mites, have been implicated in the death of large proportions of feral bee colonies in the US and surveys of beekeepers have recorded deaths of up to $82 \%$ of commercial bee colonies (Finlay et al. 1996). These mites have also been implicated in the transmission of fatal bee viruses (Hung et al. 1995). Acaricide control of mites has increased the cost and time involved in managing honey bees. The appearance of mite strains resistant to acaricides (Lodesani et al. 1995) suggests that mite control will be a continuing problem. The potential effect of mites and honey bee diseases on honey bee colonies put at risk the pollination of white clover and other cross-pollinated species.

The honey bee is not an efficient pollinator of all legume seed crops. The long corolla of the tetraploid red clover (Trifolium pratense L.) flower and the violent tripping action of the lucerne (Medicago sativa L.) flower makes them less attractive to honey bees. Pollination of these species has often been restricted owing to small numbers of alternative pollinators such as bumble bees. Attempts have been made to manage alternative pollinators. Macfarlane et al. (1983) set out management conditions for the long-tongued bumble bee species Bombus hortorum and B. ruderatus for pollination of red clover, but colony numbers have continued to be low and inconsistent. Seed certification figures in New Zealand indicate that average yield of tetraploid red clover is on average less than $200 \mathrm{~kg} / \mathrm{ha}$, and approximately half that of diploid red clovers. This compares with yields of $600 \mathrm{~kg} / \mathrm{ha}$ that have been achieved in commercial crops in which pollination has 
been good (Clifford unpubl. data). The lucerne leafcutting bee (Megachile rotundata F.) was introduced into New Zealand in 1971 to pollinate lucerne seed crops (Donovan et al. 1982). This solitary bee can be managed so that adult bee emergence coincides with the flowering of seed crops. While highly successful, and a very important pollinator of lucerne in North America, its success in New Zealand has been limited by its requirement for temperatures above $21^{\circ} \mathrm{C}$, and little wind. Apart from a few locations where topography and climate provide consistently warm temperatures, maintenance of bee numbers has been difficult. As a result their introduction has had little impact on average lucerne seed yields in New Zealand.

Osmia coerulescens L. (Hymenoptera: Megachilidae), a mason bee from Europe, has been recognised as a potential pollinator of red clover and lucerne (Tasei 1972; Tasei 1976). It is a long-tongued, solitary bee, with a similar nesting behaviour to the lucerne leafcutting bee. It builds a nest in cavities in wood or plant stems using chewed leaf material. A single egg is laid within a cell provisioned with pollen and nectar. The bee will build a series of cells within a cavity and plugs the cavity opening with further chewed leaf. On examination of pollen in trap nests, Tasei (1976) found that this bee collected pollen from lucerne, red clover, white clover and Lotus corniculatus. Parker (1981) evaluated the potential of $O$. coerulescens to pollinate diploid red clover in both cage and field trials in the US. Bee numbers in the cage increased by 8 times and an economic seed yield was produced despite there being only few bees present. In the field the bee successfully nested in artificial sites from which progeny bees could be recovered. In a separate trial conducted by Parker, $O$. coerulescens was observed collecting pollen and nesting in a cage containing Grasslands Pawera tetraploid red clover (Donovan pers. comm.). In Bulgaria, O. coerulescens was managed to supplement pollination of lucerne (Dochkova 1995). As yet, this bee has still to be managed on a commercial scale, although other mason bee species such as Osmia cornifrons (Bartra 1978), O. lignaria (Torchio 1991) and O. cornuta (Krunic pers. comm.) are being managed in commercial orchard crops.

In late 1995, cocoons of $O$. coerulescens were imported into New Zealand from France and Italy. After completion of quarantine requirements an initial field release was made. The bee re-nested in nesting blocks provided at the release site and bee numbers increased slightly (B.J. Donovan unpublished data). This paper reports on some further observations of $O$. coerulescens and discusses future research required to determine if this bee can be successfully managed.

\section{Materials and methods}

Over winter 1997, two populations of $O$. coerulescens were stored at $2-3^{\circ} \mathrm{C}$ for 9 and 10.5 months, respectively, as newly emerged adults still within their cells. These cells had been formed in 5-mm diameter paper drinking straws inserted into 6-mm holes drilled into blocks of wood. Each straw contained a series of cells, each containing an adult bee. The two populations, which will be referred to as the 1 st generation, were released at two sites for the 1997/98 summer season.

\section{Site 1}

One hundred and eighty-four cells containing bees which were produced in a quarantine cage during 1996/97 (B.J. Donovan unpublished data) were released in a sheltered gully on the Crop and Food Ltd. farm at Lincoln in mid September 1997. Pollen and nectar sources in the area included white clover, red clover, lucerne and a number of flowering weed species. The wooden blocks containing the bees were placed on a shelf at the back of a $1 \mathrm{~m}$ high $\times 1 \mathrm{~m}$ wide $\times 0.7 \mathrm{~m}$ deep shelter constructed of a corrugated iron back and "Durolite" clear plastic sides and roof. Another unused block was placed adjacent to the original block for new nesting sites. The blocks were removed and the number of new bees recorded on 21 November and 22 December 1997 and 17 April 1998.

\section{Site 2}

On 12 December 1997, 36 bees resulting from the first field release of bees in 1996/97 (B.J. Donovan unpublished data) were released in a shelter located inside an $18 \mathrm{~m} \times 6 \mathrm{~m}$ cage covered with bee-proof mesh. This cage was sited on the AgResearch farm at Lincoln. It had been planted the previous autumn with white clover, red clover and lucerne plants for pollen and nectar sources, and mallow (Malva spp.) to provide leaf for nesting material. Bee numbers were recorded on 9 January, 11 February and 28 April 1998, as above.

\section{Results and discussion}

The 1997/98 summer at Lincoln was warm and dry. Bees were observed nesting on a windy day of $17^{\circ} \mathrm{C}$ (B.J. Donovan pers. comm.). For the 5-month period 1 October 1997 to 31 March 1998, mean maximum temperatures at Lincoln exceeded $17^{\circ} \mathrm{C}$ on 143 days of the 182 days, suggesting that temperature should not have limited the bees nesting.

\section{Site 1}

Within a week of being released, newly emerged bees were observed collecting pollen and nesting. Exam- 
ination of nests on 21 November revealed a large number of dead bees which had failed to survive cool storage over the previous winter. Only 33 bees, $18 \%$ of the cells formed in the quarantine glasshouse the previous year, successfully emerged. Parker (1981) reported almost $50 \%$ mortality in overwintering bees. The bees released at this site were 10.5 months old when removed from cool storage, about 5 months longer than they would be expected to survive in nature, which suggests that old age was the probable cause of high bee mortality.

By 22 December, 31 new cells had been formed and on 2 January some 2nd-generation adult bees had emerged. At the final count on 27 April, 47 new cells containing presumably live bees at various stages of development were counted. This is a potential multiplication rate for the season of 1.42 , which is low compared with the 8-fold increase Parker (1981) reported. The negative increase recorded before 2 ndgeneration bees emerged may have been owing to the age and lack of reproductive vigour of the bees released at this site. The multiplication of the 2nd-generation adults that emerged would have also been affected by drought, which had reduced the number of flowering plants near the shelter. This would have forced the bees to forage further for pollen and may have caused dispersal and nesting away from the shelter.

\section{Site 2}

Adult bees emerged from their cells within 3 days of release at this site. From a count on 9 January emergence was $85 \%$. The bees when released were $8-9$ months old, approximately 1.5 months younger than those released at site 1 . The higher emergence suggests that bee age is critical to their ability to survive storage at low temperatures and that 9 months may be the upper limit beyond which mortality and loss of reproductive vigour will affect maintenance of bee numbers.

By 8 January, 292 new cells had been formed, and this had increased to 425 by 11 February, a potential 12.7-fold increase in bee numbers in one generation. Compared with site 1, this large increase may have been owing to the younger age and better reproductive vigour of the bees released. Also, being contained within a cage prevented bees dispersing, and the climate within the cage was less windy and slightly warmer than outside.

The increase in bee numbers in this generation was significant in realising the potential to manage $O$. coerulescens around summer seed crops. Firstly, crops such a tetraploid red clovers begin flowering later in summer. The release of the bees to emerge in summer rather than in spring as occurs naturally did not effect the bees nesting and reproducing. Secondly, white clover was the only flowering plant inside the cage for most of period during which 1st-generation bees nested. Restricting the bees to white clover pollen and nectar had no detrimental effects on $O$. coerulescens. It therefore could be an altenative managed pollinator to honey bees for white clover seed crops.

The emergence of a 2 nd generation of adult bees was first observed on 29 January, 6-7 weeks after the first bees were released. This finding was consistent with that of Tasei (1972), who found that in France at $21^{\circ} \mathrm{C}$, it took 6-7 weeks for $O$. coerulescens to develop from an egg to an adult. Nesting continued through February and March during which time lucerne and red clover were flowering in the cage. At the final assessment on 28 April, 119 live cells containing mainly adult bees remained. It was observed that the wasp parasitoid Melittobia spp. had destroyed a further 113 cells. It could not be determined how many 2 nd-generation bees emerged, as cells were destroyed by bees chewing their way out of the nest. Based on cell numbers it appears that multiplication of the 2nd generation is small compared with that of the 1 st generation. Dispersal could not be implicated in the smaller multiplication of this generation. It would appear therefore that to maximise multiplication of bees management to limit the bees to a single generation per season is required.

The 3.3-fold increase in bee numbers over the season would have been greater but for the impact of Melittobia spp., which appear to pose a serious threat to $O$. coerulescens multiplication rates. The parasitoid was first seen around the nest blocks on 8 January; however, little can be done to control them at this stage. Prolonged 2nd-generation nesting provides an opportunity for Mellitobia spp. to parasitise a large number of developing bees. Therefore, limiting the bee to one generation per season would reduce the exposure of immature bees to attack by the parasitoid. When lucerne leafcutting bees are managed over winter at ambient temperatures, Melittobia spp. pose similar problems (Macfarlane \& Donovan 1989). Cool storage of nests at $2-3^{\circ} \mathrm{C}$ from late March is recommended for control as adult Melittobia spp. are unable to survive prolonged periods of cool temperatures. A similar strategy may also prove effective for control in O. coerulescens nests.

\section{Conclusions}

The investigations support the contention that $O$. coerulescens can be managed as a pollinator of herbage legume seed crops and possibly as a replacement for the honey bee. Adult bees survived being stored at $2-3^{\circ} \mathrm{C}$ over winter, although survival and reproductive vigour was reduced once the bees were older than 9 months. Releasing the bee from cool storage in summer when 
seed crops are flowering did not appear to affect multiplication of bee numbers. O. coerulescens was able to successfully reproduce when white clover flowers were the only source of pollen and nectar. Attack by the wasp parasitoid Melittobia spp. poses a threat to increasing bee numbers; however, restricting the bee to one generation by removing from the field and cool storing as soon as adult bees develop may be a way controlling the impact of Melittobia spp.

Further research will be required before $O$. coerulescens can be commercialised. It has not yet been determined if bee numbers can be increased on seed crops of major species grown under field conditions and what the optimum bee numbers will be for good pollination of these crops. Cool storage conditions that are optimal for management of the bees and as a method for reducing the impact of Melittobia spp. also need further investigation.

\section{REFERENCES}

Bartra, S.W.T. 1978. Osmia cornifrons and Pithitis smaragdula, two Asian bees introduced into the United States for crop pollination. Proceedings of the IV International Symposium on Pollination, Maryland Agricultural Experiment Station Special Miscellaneous Publication 1: pp. 307-312

Dochkova, B. 1995. Investigation of Osmia coerulescens L. (Hymenoptera, Megachilidae) - alfalfa pollinator. I and II. Plant science 32(6): 61-66

Donovan,B.J.; Read, P.E.C.; Wier, S.S.; Griffin, R.P. 1982. Introduction and propagation of the leafcutting bee Megachile rotundata F. in New Zealand. Proceedings of the First International Symposium on Pollination, University of Saskatchewan, Saskatoon, Saskatechewan, Canada: pp. 212-222.
Finlay, J.; Camazine, S.; Frazier, M. 1996. The epidemic of honey bee colony losses during the 1995-1996 season. American bee journal 136: 805-808.

Hung, A.C.F.; Adams, J.R.; Shimanuki, H. 1995. Bee parasitic mite syndrome (II): the role of Varroa mite and viruses. American bee journal 135: 702-704.

Lodesani, M.; Colombo, M.; Spreafico, M. 1995. Ineffectiveness of Apistan treatment against the mite Varrao jacobsoni Oud. in several districts of Lombardy (Italy). Apidologie 26: 67-72.

Macfarlane, R.P.; Griffin, R.P.; Read, P.E.C. 1983. Bumble bee management options to improve 'Grassland Pawera' red clover seed yields. Proceedings of the New Zealand Grassland Association 44: 47-53

Macfarlane, R.P.; Donovan, B.J. 1989. Melittobia spp. as parasitoids of bumble and lucerne leafcutting bees and their control in New Zealand. Proceedings of the New Zealand Weed and Pest Control Conference 42: 274-277.

Matheson, A. 1993. World Bee Health Report. Bee world 74: 176-212.

Parker, F.D. 1981. A candidate red clover pollinator Osmia coerulescens L. Journal of apicultural research 20: 62-65

Tasei, J.N. 1972. Observations preliminaires sur la biologie d'Osmia (Chalcosmia) coerulescens L., (Hymenoptera Megachilidae), pollinisatrice de la luzerne (Medicago sativa L.). Apidologie 3: 149-165.

Tasei, J.N. 1976. Recolte des pollens et approvionnement du nid chez Osmia coerulescens L. (Hymenoptera, Megachilidae). Apidologie 7: 277-300.

Torchio, P.F. 1991. Use of Osmia lignaria propinqua (Hymenoptera: Megachilidae) as a mobile pollinator of orchard crops. Environmental entomology 20(2): 590-596. 